dades de venda, temos:

$$
\frac{P \text { equ }}{P C A P}=\frac{F}{P C A P} \times \frac{1}{b-a}
$$

Como o autor afirma que o Pequ. da Toyota ê $30 \%$ da capacidade, temos:

$$
\begin{aligned}
& 0,3=\frac{F}{P C A P} \times \frac{1}{b-a}, \quad \text { donde } \\
& 0,30(b-a)=\frac{F}{P C A P} \text { o que significa que } 30 \%
\end{aligned}
$$

da margem de contribuiçăo unitária correspondem ao custo fixo por unidade na capacídade.

Tomando (por cima) um automóvel que tem o preço, sem imposto, de Cz $\$ 800.000,00$, e a usual participação de custo variável de $57 \%$ de material comprado e $23 \%$ de mãode-obra, teríamos $0,2 \times 800.000=\$ 160.000,00$ de margem de contribuição e corresponde a somente $6 \%(0,3 \times 0,2)$ de custos fixos. Uma comparação, feita pelo resenhista, com dados alemães, chegou a resultados similarmente baixos para os custos fixos $(40 \%$ de mão-de-obra, $50 \%$ de material comprado e $5 \%$ de custos fixos).

Nota-se aqui um ponto sobre flexibilidade que o autor pretende desenvolver futuramente, pois ensina-se que flexibilidade de máquinas e homens sai cara em custos fixos (investimentos).

O livro trata dos seguintes assuntos, conforme seu sumário (índice):

- Flexibilidade

- SFM - Sistemas Flexiveis de Manufatura

- FSE - Fabricação Sem Estoques

- Comparaçẫo no SFM vs FSE

Para quem tenha conhecimentos elementares de procedimentos japoneses, o livro começa a se tornar valioso a partir do conceito de flexibilidade na preparação de mắquinas (pág. 107). Em seguida, a partir da linha de produção em "U", das discussōes sobre "layout" (pág. 113) e célula (pág. 115), chega-se à conceituação da produção flexível (pág. 120) e a sua distínção da automaçăo (pág. 119). Nota-se que o autor está usando os seus profundos conhecimentos mais nesses capítulos finais - aliás, ele assina alguns gráficos com "autor".

Para todos, e repito, todos os envolvidos em processos produtivos, o livro tem alto valor, pois mostra procedimentos modernos, usados pelos atuais líderes de processos de produtividade - os japoneses. Os defeitos enumerados não pesam quando o livro é usado como introdução ao estudo da engenharia da fábrica. O livro, assim, deve ser usado em cursos de administração da produção e manufatura, em cursos de graduaçăo e pós-graduação de administraçăo, e como introdução em cursos de engenharia de produção. Não deve ser leitura única, pois exige conhecimentos prévios de engenharia industrial. Em treinamento de executivos, o livro pode ser considerado altamente valioso, combinado, evidentemente, com filmes e transparências.

Como sempre, faz falta um índice alfabético remissivo, que dá muito trabalho se feito manualmente, mas que, com um computador, leva pouco tempo.

\section{ECONOMIA AGRICOLA: O SETOR PRIMÁRIO E A EVOLUÇÃO DA ECONOMIA BRASILEIRA}

MARCOS CINTRA C. ALBUQUERQUE E ROBERT N. V. C. NICOL. , Sáo Paulo, McGraw-Hill, 1987.

\section{Por Solival Silva e Menezes}

Mestrando em Economia do IPEUSP e em Administração de Empresas da EAESP/FGV.

Esta obra, escrita por dois importantes economistas da Escola de Administraçäo de Empresas da Fundação Getúlio Vargas, representa uma importante contribuição para a compreensão do papel do setor primário e dos ciclos agrícolas na dinâmica da industrializaçăo brasileira.

Evitando a mera referếncia teórica, os autores estabelecem, já no capítulo inicial, um interessante painel que vincula o tema tratado à teoria existente sobre o assunto, destacando-se a menção às idéias de David Ricardo que, em seus The Principles..., inaugura a preocupação dos economistas em associar a questão agrícola aos problemas específicos do capitalismo industrial. Tratam, também, das idéias de economistas contemporâneos, como W. A. Lewis, J. C. Fei, G. Ranis, M. H. Watkins, J. Mellor e Hymes e Resnick.

A teoria rícardiana é examinada, tendo como referência năo apenas os originais desse clássico, mas também interpretações recentes, como as de Irma Adelman, Thweat e Barber. Verificam de perto as análises de J. Mellor na tentativa de mostrar o papel da agricultura no desenvolvimento e tratam de forma atenciosa o modelo de Lewis com oferta ilimitada de trabalho. Também expandem a análise de Lewis através do trabatho de Fei e Ranis, passando de uma agricultura de pequenos lavradores para uma economia de maior expressão capitalista, com assalariados e com um processo de acumulação consubstanciado na elevada propensão 
a poupar dos proprietários agrícolas

Marcos Albuquerque e Robert Nicol vão buscar, a partir do segundo capítulo, entender o papel dos grandes ciclos agrícolas, tendo como pano de fundo a própria historia economica brasileira, fazendo uma interessante abordagem às primeiras décadas de colonizaçăo portuguesa e interpretando o papel do açúcar e o caráter de enclave da economia do século XVII. Examinam, também, - ciclo da mineração e o Tratato de Methuen, mostrando de que modo contribuíram para a formação de uma naçăo com potencial econômico suficiente para atrair o interesse dos parceiros de Portugal, bem como o ciclo do café, que representou um passo importante na busca da modernização e do crescimento econômico do país. Os autores não deixam escapar algo fundamental para compreender a dinâmica da industrialização brasileira, que é o papel do Estado e sua associação com a agricultura. Ocupam-se de quase um século de agricultura (18501930), destacando a ausência de uma revoluçāo agrícola no Brasil e fazendo um corte analítico por produto, onde notamos o papel crucial do café na geraçăo de mercado para produtos manufaturados, na vinda dos imigrantes, na compra de equipamentos e no processo de acumulação, elementos esses que seriam decisivos na gênese da industrialização recente do país.

No quinto e último capítulo, os autores tratam especificamente dos vinte últimos anos que precederam a década de 1980 e, para isso, utilizam uma profusão de dados bem trabalhados que ajudam a ressaltar a importância da agricultura no Brasil e permitem discutir com bom embasamento questöes como produtividade, posse da terra, deficiências de infra-estrutura e o processo de urbanização. Analisam o papel específico da agricultura como liberador de mão-de-obra para a indústria, como fornecedor de matérias-primas e alimentos e no aporte de capitais, ressaltando também o seu desempenho no modelo de substituição de importaçoes e no contexto do modelo exportador, além do papel de gerador de demanda por bens industriais.

Abordam, ainda, a expansão das fronteiras agrícolas, o favorecimento dos preços internacionais e a abundância de crédito como razoes do sucesso do setor e entram na polêmica da reforma agrária, recomendando que se pratiquem políticas complementares de emprego e de incentivo à produção agrícola nos latifúndios, como alternativa ao simples incentivo à aglomeração de terras nos grupos de pequenas propriedades, e as propostas convencionais de redistribuição de terras.

Por tudo isto e pela clara qualidade didática do livro, podemos concluir que se trata de uma interessante contribuição para compreender o desenvolvimento nacional e de uma importante obra de economia agricola que trará novas luzes aos interessados pela área. $\square$

\section{GUILHERME MARECHAL OU \\ O MELHOR CAVALEIRO DO MUNDO \\ (Tradução de Renato Janine Ribeiro)}

GEORGES DUBY, Rio de Janeiro, Ediços do Graal, 1988, 212 págs.

Por Atranio Mendes Catani

Professor da Faculdade de Educaçăo da Universidade de São Paulo (USP).

Inglaterra, 14 de maio de 1219 , por volta de meio-dia: um cavaleiro de 73 anos, cercado de seus familiares, criados, religiosos e ainda bem lúcido dá suas ûltimas ordens, despede-se daqueles que mais ama e pöe fim a uma agonia que durou cerca de três meses. Nessa época, em que "o costume sustenta a ordem no mundo", as belas mortes se constituem em verdadeiras festas. $O$ ritual da morte à maneira antiga năo era uma partida furtiva, esquiva, e sim uma chegada lenta, regrada, governada - "um prelúdio, passagem solene de uma condiçăo para outra, superior, mudança de estado tão pública quanto as bodas, tão majestosa quanto a entrada dos reis em suas leais cidades" (p. 10).

O acompanhamento do ritual da morte de um célebre cavaleiro medieval, ocupando todo um capítulo, dá início ao excelente livro de Georges Duby, Guilherme Marechal ou o Melhor Cavaleiro do Mundo, traduzido de maneira impecável pelo Professor Renato Janine Ribeiro. Professor do Collège de France (Paris), Duby é na atualidade um historiador reconhecido internacionalmente pela sua capacidade de aliar sua extraordinária erudição a virtude de tornar o periodo medieval acessível ao grande público. E autor, entre tantas outras obras, de Tempo das Catedrais, As Três Ordens ou - Imaginário do Feudalismo, O Ano Mil, Le Chevalier, la Femme et le Prêtre.

Duby segue o percurso de Guilherme Marechal através de um manuscrito em pergaminho, verdadeira canção de gesta encomendada pelos herdeiros de Guilherme. $O$ objetivo: tornar o Marechal presente, vivo, uma vez que a dinastia que levava seu 